\title{
BRITISH ENTRY INTO THE COMMON MARKET:
}

\section{A BRITISH VIEW}

\author{
Brian L. Crowe*
}

The debate about Britain's entry into the Common Market has, at least in Britain herself, tended to focus on such relatively short-term matters as the cost of living and other immediate economic effects or the changes it would make in detailed aspects of the British way of life. This kind of debate is no doubt necessary and useful. After all, the short-term effects are not only the ones which have the most noticeable impact but ultimately become long-term ones. Nevertheless, this kind of debate ignores the very considerable changes which have been taking place steadily in the years-indeed decades-since the Second World War. British entry into the Common Market can be understood only in the longer-term perspective of British experience over this period and in the light of what we can expect in the future. We have to look at both the historical events and processes which brought us to our present situation and the prospects which are open to us.

To see how we got where we are now, we must go back nearly three decades and look at our position in I945. Our future then was surely the least clearly charted of all the major participants in the Second World War, whether victors or vanquished. The United States and the Soviet Union were secure as superpowers. Germany, Japan, and Italy were all defeated and reconstruction had to be their single-minded aim. France had also been defeated; and while she, too, had overseas responsibilities, she had inevitably sacrificed less in an economic sense than we. We, having seen the war through from I94I to a victorious conclusion and having borne the burden of it alone from the fall of France until I94I, outwardly looked extremely powerful. With armies spread around the world we could be forgiven if we thought that the British Empire was at the height of its strength.

But even in the years immediately after the war, the strains were beginning to show. The burden of fighting the Communists in Greece grew too heavy for us and we passed it to the United States. We found ourselves unable to solve the Palestine problem. We found that even as an apparently powerful victor-nation, unlike the United States and even the Soviet Union, our power had been undermined by the sacrifices of the war. We were, of course, a much smaller country than either of these; but, in addition, we continued to bear a combination of burdens which were too much for us.

The burden of debt was a crushing one. To finance the war we had liquidated most of our very considerable foreign assets and, because most of our production had to go into the war effort rather than exports, had accumulated huge debts arising

* First Secretary, British Embassy, Washington, D.C. This paper was originally presented on February 24, 1972, to a seminar sponsored by the Center for Commonwealth Studies, Duke University. 
out of the imports of the raw materials on which we had depended. Those debts remain with us today in the shape of the sterling balances. Their composition and ownership have changed, but the fact remains that we have never been able to repay the debts accumulated in the common defence.

Our economy was gravely weakened by the obsolescence of our industry which during the war had neither the funds nor the capacity to set aside resources for industrial replacement.

To compound our burden, the military commitments which we assumed around the world were greater even than those of the superpowers. Over the years they have proved extremely expensive. Of course it was not only military victory, but also our own traditions and habits of thought which prevented us from curtailing these responsibilities, or questioning the belief that it was natural for us to police large parts of the world and to defend countries far away.

Thus, in the first decade after the war we found ourselves preoccupied with many problems and responsibilities which left us little time or inclination to wonder whether our world could continue for long. The conversion of our Empire into the new concept of a Commonwealth of Nations held the attention of governments and people alike. Looking back, it was surely something of an achievement successfully and, on the whole, peacefully to bring to independence a large number of countries which remain our friends to this day. If some people accused us of taking too long in doing this and condemned us as out-of-date colonialists, we found the justification for our policy in the Belgian Congo, where we saw what a premature withdrawal from responsibility could produce. We believed in the Commonwealth ideal, the ideal of a like-minded group of nations brought up in the British connection which could be a force for peace and progress and on which our foreign policy and our influence in the world could be based.

But the world around us was changing in ways which were not compatible with our view of ourselves. The superpowers continued to grow in strength relative to the other countries of the world, including ourselves. Devastated Europe went through a period of reconstruction with generous American aid and the first moves towards Western European unity were made. The division between Eastern and Western Europe was formalized and we encouraged, if we did not join, the defence aspects of European integration because of the Soviet threat. But we refused to join in the moves towards European political unity because our main interests still seemed to lie in the Commonwealth and in our relations with our close wartime Western ally, the United States. After the collapse of the European Defence Community in 1952, Europe moved toward the Treaty of Rome. We took no part in this process. Indeed, all our attempts were directed at including ourselves in a free trade area covering all of Western Europe which the Six countries of the new EEC saw as attenuating their ideal of political unity. They rejected our advances. Even as we formed the European Free Trade Area of the seven in parallel to the EEC of the 
Six, it was already clear that we should have to think again about our European policies.

There were other developments in the world which we could not ignore if we were not to find events passing us by. The volume of world trade was increasing far more between the industrial nations themselves than between developed and developing countries. We found that our own trade was more important with the United States, with Europe, even with industrialized South Africa, than with the less developed countries of the Commonwealth. As a medium-sized, industrialized European country it became increasingly plain that we could not base our foreign policy on a Commonwealth of independent countries in the way that formerly we could on a united British Empire. The newly independent countries were too diverse, too separated-each with their own regional interests and their own governments of varying political persuasions-to cooperate with or even be sympathetic to our major international preoccupations (for example, the Atlantic Alliance and the East-West confrontation in Europe). Similarly, our major security interests made it difficult for us to share their attitudes of non-alignment; and our weak economy, impossible to help them with economic aid to the extent they demanded. In addition, divisive issues within the Commonwealth-such as the controversy in IndiaPakistan and apartheid in South Africa and, in recent years, Rhodesia-have shown how impracticable it is to think of the Commonwealth as a political unit.

And so, at the end of the I950's, we found ourselves with a proud past but no clearly discernible future. For too long we had tried to fulfill the role of the third of the great powers, only to find that economically we could not manage it. In size and population we were a middle-range power, not a great one; we were comparable to our European neighbours and not the United States or the Soviet Union. In Dean Acheson's now famous words, we had lost an Empire but not yet found a role. The recent past had shown what we could not do. A look into the expected future showed the rather limited choice that lay before us. It is worth outlining some of the assumptions about this future, against the background of which we had to make our decision.

The first reasonable assumption was the position of the superpowers. Of these, we could be confident that the United States would remain the world's strongest power and would increase its lead over individual European countries. It would no doubt also continue the increasingly evident trend of being preoccupied with domestic concerns and under increasing pressure to cut back overseas commitments.

The Soviet Union, while preoccupied with China, would maintain, or try to maintain, a tight hold over Eastern Europe. Although today it is unfashionable to say so, we must expect it to remain a Soviet objective to weaken Western Europe, forestall its integration, and encourage the destruction of links between Western Europe and the United States.

With regard to Western Europe, there could be no doubt that the dominating factor in the next decades would be the ECC. Within the existing EEC, Germany was 
already becoming the most powerful member, at least economically. In the rest of the world, China would come out of its isolation; and Japan would forge a new and more self-confident identity. The Commonwealth would continue to be a group of countries, bound together by historical, economic, and other ties, which would find it useful to discuss world problems. But the Commonwealth countries would be no more able in the coming period than they had been in the past to produce a concerted line of action or protect their interests as a group vis-à-vis the rest of the world.

In the economic sphere, world trade would continue to grow, if more slowly than in the recent past. Countries, or groups of countries, with large markets and largescale resources and investment capabilities would expand at a faster rate and become economically stronger than countries less well placed.

Against this background, the real choice facing us was whether to continue as we were, trying to maintain the existing pattern of international relationships, or to join the European Economic Community. Other alternatives which have been canvassed have not proven realistic on examination. Basing ourselves on the Commonwealth has already shown itself not to be a viable choice. A North Atlantic Free Trade Area has sometimes been advocated but the concept is vague, including as it sometimes does even Japan and Australia. Even if such a proposal were viable on economic grounds, it lacks the element of political cohesion necessary to counterbalance the fact that we are smaller than the major countries or groups we should be dealing with inside and outside a NAFTA. With the political dimension missing, the idea has always lacked appeal, and it has never got off the ground as a serious alternative.

Thus, joining the Common Market seemed the only sensible answer. We naturally expected to benefit from membership. We expected and expect the economic benefits of increased scale-a reference not only to the size of the market, but also to greater market stability, greater growth, and greater access to the scale of resources needed in modern technology than we have been able to provide for ourselves.

But important as these economic benefits are, even more important is the fact that membership would give us an influence which we would not otherwise have in the development of Europe itself and of Europe's relations with other parts of the world. What is at stake here are Britain's own relations for the foreseeable future with her closest neighbours as well as the future relations of Western Europe with the superpowers, with the developing world, with Japan and China; these relationships will involve major issues of international trade and finance as well as the central issues of war and peace. All these fields would be of great concern to us whether we were members of the Common Market or not, both because of their direct effect on Britain and because they would shape the world we should be living in. But Britain has half the population of Japan, a third that of the EEC, a quarter that of the United States. A country of fifty-five million people could not be in a strong position to influence these events where the other chief participants were major 
economic and political entities like the United States, the Soviet Union, the EEC, Japan, and perhaps China. We should be far better placed to help shape our own future as a major member of a strong European Community than as a relatively small country independently attempting to protect our interests.

For all of these reasons successive British governments, starting more than ten years ago, decided that we should throw in our lot with the European Communities. In the best of all possible worlds, there would have been no price to pay nor risks to take either by us or by any of our friends. This being a less than perfect world, we have had to settle for less than the ideal; but through the skill of our negotiators and through the keenness of our European friends to have us in, we have emerged with a generally good deal for everybody, including our traditional Commonwealth trading partners, particularly New Zealand and the Caribbean sugar-producing countries, for whom reasonable and continuing access to the British market was the only alternative to serious economic problems amounting in some cases to disaster. It is a very dubious argument that we as a country should sacrifice our own future because we obtained only a good, and not the best possible, result for our friends.

Just as many people in Commonwealth countries have always been anxious about British entry into the EEC, Americans have generally-perhaps instinctively - supported it. Conceivably this support rests on the somewhat misleading analogy of the federation of the United States of America. But now that entry has become a reality, it is no secret that many people in the United States have also started to question whether the Common Market and its enlargement are such a good thing after all. Many of these questions relate to its short-term impact effect. It is now time to turn to some of these doubts which have been expressed in recent months.

The Common Market is sometimes held to be economically damaging to other countries. It is true that change inevitably does cause some problems of readjustment, but the matter must be kept in perspective. Experience to date has been that the Common Market has greatly increased overall trade with other countries and most notably with the United States. In fact, trade between the Common Market and the United States has tripled since the Common Market was founded in 1958, and it is still growing rapidly. As a percentage of total United States exports, exports to the Six increased from sixteen per cent in $195^{8}$ to 19.5 per cent in 1970 . Even in the sensitive area of agriculture the United States exports in 1970 matched the peak figures for 1966 , increased by $\$ 243$ million in 1979 , and were considerably greater than the figures for pre-Common Market days. Agricultural exports vary from year to year, but United States agricultural exports to the Six which were about $\$ 800$ million in 1958 , reached the level of more than $\$ \mathrm{r} .5$ billion in 1970 . It was widely argued that 1970 represented a freak high. Now, USDA figures released in February, 1972, indicate a record level of $\$ 1.83$ billion in I97I. It would be difficult to show that United States agriculture as a whole, even in the worse years, has suffered from the Common Market since the Six have consistently taken around the same proportion, about twenty-two per cent to twenty-three per cent, of all United States 
agricultural exports. British accession to the Community, by the lowering of our average industrial tariffs by about a fifth to the Common Market level-which is already substantially below the United States level-and by increasing our rate of growth and therefore demand for imports, can also be expected to provide further opportunities for increased trade.

Two particular problems which have worried some of our friends about the Common Market and about our entry into it are the Common Agricultural Policy (CAP) and the question of special trading arrangements with third countries. Although United States agricultural exports overall have not suffered, the CAP is seen as a threat to some sectors of American agricultural exports. The fact is that with fourteen per cent of the Community's population on the land, many in farms which are too small and too inefficient to be competitive, the member countries are faced with immense social and political problems which cannot, in demoaratic countries, be solved by hard doctrines of laissez faire economics. They are much the same problems as the United States faced in the 1950 's. It is easy for those who already have an efficient agriculture, as both the United States and Britain have, to criticize those who are still seeking a solution. But a solution is on the way; the member governments of the Community are doing a great deal to modernize and rationalize farming in Europe. Fourteen per cent of the population on the land is already a considerable reduction of the twenty-five per cent of fifteen years ago. As for the trading and association arrangements entered into by the Common Market, criticisms here often do not recognize the real problems of the developing countries which many of these arrangements are designed to meet. Britain is as committed to the principles of multilateral trade as anybody, but we also have a direct responsibility toward developing Commonwealth countries, who depend for their livelihood on access to the British market and for whom there are no alternative markets. This is why we insisted that the enlarged Community should assume responsibility for the developing Commonwealth just as it has for the overseas partners of the present members.

The European Community has already done much to eliminate the traditional divisions and weaknesses which so bedevilled Europe in the past. The enlarged Community consolidates this process, removes a cause of tension and potential instability in Europe and forestalls the resurgence of old enmities and tempting opportunities for mischiefmaking and disintegration on the part of those who do not wish us well. It also opens up whole new perspectives in diplomacy and defence.

With political cohesion and unity, we in Europe should be able to bear a greater share of the common burden of defence. A start has already been made by increased European contributions to the common defence through the so-called European Defence Improvement Program and other measures. Major developments cannot happen overnight since we shall still be a collection of ten individual countries. But with the central issue of enlargement now decided, we should certainly hope to find the necessary political will to establish new ways of working together, new 
means of coordinating our resources, and new possibilities commensurate with our political and economic potentialities.

Political strength in Europe, based on the economic union provided by the Common Market and the political cohesion which will go with it, can also be expected to contribute to the improvement of East-West relations. The Soviet Union has consistently opposed greater unity in Western Europe precisely because fragmentation would have increased their opportunities to exploit our weaknesses. Western Europe cannot face the East with real self-confidence so long as it is disunited. A viable union of Western Europe, on the other hand, can provide a firmer basis for real relaxation of tension with the Communist world and for a balanced reduction of the armaments which at present lay so heavy a burden on both sides.

With President Nixon's visits to Peking and Moscow, it is hardly necessary to catalogue the changes and the evolution which are taking place in international relationships. We in Europe have contributed to these changes, but we have also foreseen them, in general if not in detail, and helped to make them constructive. In doing so it can fairly be said that we are keeping the best of the old relationships in forming the new ones.

In some ways the enlarged EEC may be a more difficult partner for the United States to deal with. Cooperation on a basis of equality is also liable to mean less chance of one partner getting his way all the time. Nevertheless, the cooperation is more effective and the partnership stronger. Events since August, $197 \mathrm{x}$, have demonstrated both the differences that can arise and our continued interdependence, not to mention the dependence of the rest of the world on our success in coping with our problems. President Nixon's Foreign Policy Report for 1972 expresses the consequences of what he calls the "striking change in political as well as economic relations across the Atlantic." It shows also where all our interests lie. He said:

The United States is realistic. This change means the end of American tutelage and the end of the era of automatic unity. But discord is not inevitable either. The challenge to our maturity and political skill is to establish a new practice in Atlantic unity-finding common ground in a consensus of independent policies instead of in deference to American prescriptions.

This essential harmony of our purposes is the enduring link between a uniting Europe and the United States. This is why we have always favored European unity and why we welcome its growth not only in geographical area but into new spheres of policy .... Two strong powers in the West would add fexibility to Western diplomacy, and could increasingly share the responsibilities of decision .... As this political will develops, it will facilitate cooperation in the wider Atlantic relationship. 